Geliș Tarihi: 02.01.2019

Kabul Tarihi: 17.04.2019
Mediterranean Journal of Humanities mjh.akdeniz.edu.tr IX/1 (2019) 241-256

\title{
Zikzak: Bir Ortaçă̆ Motifinin Anadolu Yansımaları
}

\author{
Zigzag: Reflection of a Motif in Anatolia
}

\section{Emre KOLAY * Orçun ERDOĞAN **}

$\ddot{O}_{z:}$ Zikzak, mimari ve el sanatları alanında binlerce yıldır uygulanmış ve Anadolu'nun mimari süsleme dağarcığında da taş, tuğla ve freskolarda tercih edilmiştir. Antikçağdan bu yana mimaride bir süsleme ögesi olarak kullanılıyor olmasına karşın, motifin kemer ve çevresinde bir bezeme ögesi olarak yaygın hale gelmesi özellikle Ortaçağ'da başlamaktadır. Avrupa ve Ortadoğu'da uygulanmış zikzak örneklerinin incelendiği çalışmalarda Anadolu örneklerinin eksikliği, söz konusu süslemenin rotasının yorumlanmasında bir takım eksikliklere sebep olmaktadır. Bu bağlamda bu çalışmada Anadolu'da uygulanan zikzak örneklerinin kronolojisinin ortaya çıkarılması ve yayılım alanlarının gözden geçirilmesi amaçlanmıştır. Bu noktadan hareketle, öncelikle zikzak örgesinin mimari süsleme programı kapsamındaki çeşitlemeleri chevron, testere dişi ve zikzak terimleriyle tanımlanmaktadır. Ardından bu zikzak süsleme çeşitlemelerinin kemer ve çevresindeki Anadolu mimarisi uygulamaları sırasıyla Geç Antikçağ, Doğu Roma, Anadolu Selçuklu ve Beylikler dönemi örnekleri kapsamında incelenmekte; kronoloji temel al1narak Ortadoğu ve Avrupa örnekleri ile bağlantıları kurulmaktadır. Bu çalışmada, söz konusu süslemenin mimarideki uygulamalarının dış kaynaklı olduğu; diğer bir deyişle Anadolu'nun bu motife kaynaklık etmediği ileri sürülmektedir.

Anahtar sözcükler: Zikzak, Köpek Dişi, Testere Dişi, Romanesk

Abstract: The zigzag design has been employed in architectural and handicraft ornamentation for thousand of years and was included in the repertoire of architectural decoration of Anatolia in stone, brick and fresco/red ochre materials. Although the zigzag has been employed in architecture from as early as Antiquity, its use on arches as an ornamental element became a phenomenon especially during the Middle-Ages. The lack of Anatolian examples from among the large number of articles concerning the architectural zigzag in Europe and the Middle East, resulted in scanty interpretation upon the interaction route of this ornament. From this point of view, this study examines the chronology of the zigzag design in Anatolia and its use and and aims to revise the dissemination of the design. In this respect, firstly, the variations of the architectural zigzag design are described by the terms chevron, saw tooth and zigzag. Secondly, the Anatolian examples of the architectural zigzag design are examined chronologically and these examples are compared with those from the Middle East and Europe. It is suggested on the basis of the data discussed in this article that the ornamentation in question originates from outside of Anatolia.

Keywords: Zigzag, dog tooth, saw tooth, radiant freeze, Romanesque

* Dr. Arş. Gör., Hatay Mustafa Kemal Üniversitesi, Fen-Edebiyat Fakültesi, Sanat Tarihi Bölümü, Hatay. emrekolay55@gmail.com, https://orcid.org/0000-0002-5696-324X

** Dr. Arş. Gör., Hatay Mustafa Kemal Üniversitesi, Fen-Edebiyat Fakültesi, Sanat Tarihi Bölümü, Hatay. erdoganorcun2@gmail.com, https://orcid.org/0000-0001-6747-0136 
Giriş

Zikzak formu, çeşitli coğrafyalarda ortaya çıkmış olan medeniyetlerin ürettikleri eserlerde binlerce yıldır karşımıza çıkmaktadır. Bu form, özellikle Ortaçağ boyunca gerek Avrupa gerek Ortadoğu ve Anadolu topraklarında mimari süsleme unsuru olarak kemerlerde, sütun ve sütunçelerde, saçaklarda, lento ve hatta bazı duvar resimlerinde yaygın bir şekilde uygulanmış, gerek Hristiyan gerekse İslam mimarisinde özellikle ilahi simgeler olarak yorumlanmıştır (Konumuz kapsamı dışında kalan zikzak sembolizminin detayları için bk. Moss 2000, 171-182; Curcic 2012, 307-334; Duggan 2017, 237-238). Bu çalışmada, söz konusu dönem içinde kemer ve çevresinde farklı kompozisyonlarda uygulanmış olan zikzak motifinin Anadolu'daki mimari örnekleri incelenecektir.

Bazen birbirleriyle yakın anlamlarda, bazen de zikzak formunun çeşitlemeleri olarak verilen ve chevron, testere dişi, köpek dişi, zikzak, ışınsal friz gibi terimlerle adlandırılan söz konusu formun, Ortaçağ' da başlıca üç farklı çeşitlemeyle kemer ve çevresinde mimari süsleme unsuru olarak uygulandığı söylenebilir.

Birinci çeşitleme olarak tanımlayabileceğimiz formda, genellikle taşa işlenmiş olan zikzak üç boyutlu bir görünüm kazanarak plastik süsleme ögesine dönüştürülmüş ve kırık bir silme hattına evrilmiştir. Batı ve genel mimarlık terminolojisinde yaygın biçimde kullanıldığı üzere bu ilk çeşitlemeyi chevron olarak isimlendirebiliriz.

İkinci çeşitleme olarak tanımlayabileceğimiz formda, tuğlalar duvar yüzeyinden yak. 45 derecelik açıyla çıkıntı yapacak şekilde ya da üçgen biçimde kesilerek üç boyutlu zikzak motifi oluşturulur. Doğu Roma mimarlık terminolojisinde genellikle testere dişi ya da köpek dişi olarak adlandırılan bu formu, nispeten daha yaygın kullanımı dolayısıyla testere dişi terimiyle tanımlamaktayız.

Üçüncü çeşitleme içinde ele aldığımız form minyatürler, duvar resimleri ve mozaikleri ile çeşitli küçük el sanatları gibi hemen her örnekte temelde iki boyutludur. Bu çeşitlemede forma, kimi örneklerde çoğunlukla basit perspektifler kullanılarak üç boyutlu bir görünüm kazandırılmaya çalışılmıştır. Yine de iki boyutlu karakteri ve dolayısıyla arkaik biçime en yakın form olması açısından bu çeşitlemeyi zikzak olarak adlandırmaktayız.

Malzeme, kullanım alanı ve kompozisyon bakımından birbirleriyle birtakım farklılıklar göstermesine rağmen, mimari plastik özelliğe sahip olması ve temelde zikzak formundan geliştirilmesiyle, chevron ve testere dişi motiflerinin benzer karakterlerde olduğunu söyleyebiliriz. Öte yandan zikzak olarak adlandırdığımız form, mimaride duvar yüzeyinden çıkıntı yapmaz ve dolayısıyla basit perspektiflerle yapılan üç boyutlu yanılsamalar dışında chevron ve testere dişi gibi üç boyutlu mimari plastik niteliğinden yoksundur.

\section{Anadolu}

\section{Geç Antikçağ ve Doğu Roma Dönemi Örnekleri}

Anadolu'da Geç Antikçağ ve Orta Çağ Hristiyanlık dönemi mimarisinde kemer ve çevresi zikzak süsleme uygulamaları testere dişi ve zikzak olmak üzere iki çeşitleme olarak karşımıza çıkar. Geç Antikçağ'dan tespit edilen en az iki testere dişi süslemeli yapı örneği, zikzak çeşitlemesinin erken uygulama alanlarını göstermesi açısından oldukça değerlidir.

Likya'nın doğu kıyı yerleşmelerinden biri olan Olympos antik kentinin kuzey bölümünde Mozaikli Yapı olarak anılan ve konut olarak kullanıldığı düşünülen bir yapı bulunmaktadır. Gerçekleştirilen kapsamlı kazı çalışmaları ve araştırmalar sonucunda, bu yapının inşasının V. yüzyılda başladığı, VI. yüzyıl başında tamamlandığ 1 ve yapının VII. yüzyıl ortasına kadar kullanıldığı ileri sürülmüştür (Öztaşkın \& Öztaşkın 2012, 336; Öztaşkın 2018, 618). 


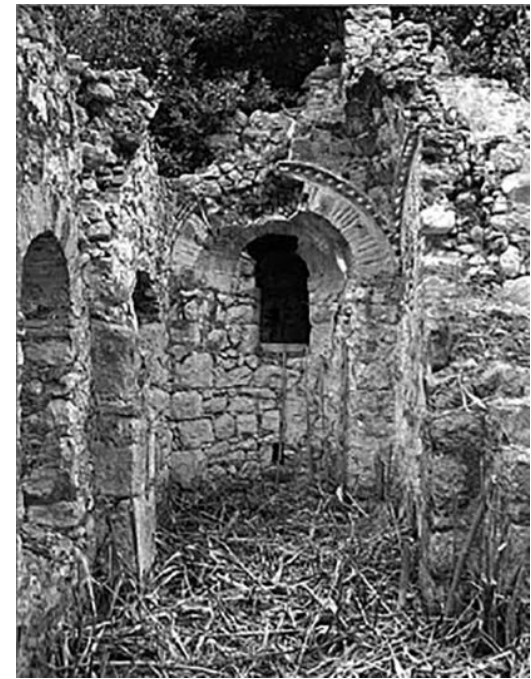

Fig. 1. Olympos Mozaikli Yapı, C odası (Öztaşkın - Öztaşkın 2012, Res. 3d)

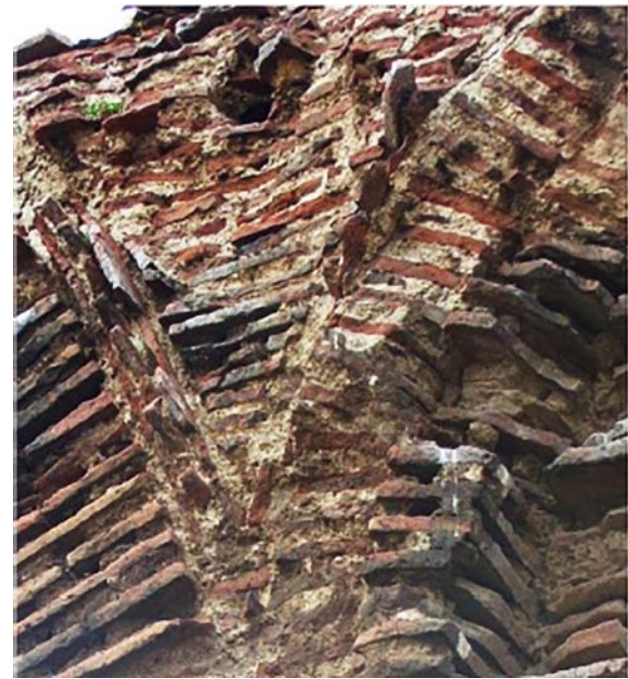

Fig. 2. Philadelphia Aziz İoannes Kilisesi, kuzeydoğu ayağı, doğudan (Erdoğan 2015, Fig. 13)

Tuğlalarla oluşturulmuş söz konusu testere dişi süsleme, yapının mekânları içinde yer alan bazı kör kemerler ile odalardan birindeki nişin kemeri üzerinde, kemerleri çevreler şekilde uygulanmıştır (Öztaşkın \& Öztaşkın 2012, 332) (Fig. 1). Özellikle Orta ve Geç Doğu Roma dönemleriyle ilişkilendirilen kemer üstü testere dişi uygulamasıyla iç mekânda ve bir Geç Antikçağ yapısında karşılaşılması, oldukça nadir ve dolayısıyla dikkat çekicidir.

Aynı dönemden günümüze ulaşabilmiş ikinci örnek, Lidya'daki Philadelphia antik kentinin merkezinde bulunan Aziz Ioannes Kilisesi'dir. Buchwald tarafindan Iustinianus dönemine tarihlenen (Erdoğan 2015, 269. Ayrıca bk. Buchwald 1981, 317-318; Buchwald 1984, 209-215; Karydis 2011, 181-182; Karydis 2012, 122-138) bu kubbeli kilisenin kuzeydoğu ayağı ile olas1lıkla kuzeybatı ayağının cephelere bakan yüzeylerindeki iki kademeli kör kemerlerin üst kısımları, yine tuğladan testere dişi süsleme şeridiyle çevrelenmiştir (Fig. 2). Orta Doğu Roma döneminde birtakım onarımlar geçirmiş olmasına rağmen, birçok ipucu, bu testere dişi hareketlendirmelerinin yapının VI. yüzyıldaki ilk inşa evresine ait olduğunu düşündürmektedir (Erdoğan 2015, 270). Philadelphia örneği, Olympos'taki uygulamayla olası tarih yakınlığı ve biçim açısından büyük bir benzerlik taşımaktadır. Öte yandan cephe hareketlendirmesi amaçlı kullanımı ve bu özelliğiyle Orta ve Geç Doğu Roma dönemi yapılarına yaklaşmasıyla Olympos örneğinden ayrılır.

Testere dişi tuğla şeridin Geç Antikçağ'da Anadolu'da kemer çevresinde kullanımı, örneklerden de anlaşılacağı üzere oldukça sınırlıdır ve bu durum şimdilik XII. yüzyıl içlerine kadar aynı şekilde devam etmiş gibidir. Likya'daki Myra'da, ilk inşa evresi XII. yüzyıla tarihlenen Alakent Kilisesi'nin güney cephesindeki pencere kemeri ve naosa giriş kapısının kemer üstü, tuğladan testere dişi ile hareketlendirilmiştir (Akyürek 2010, Res. 6, Res. 11; Akyürek 2015, 17 fig. 1, fig. 6; Akyürek 2018, 83, 87, 112 Çiz. 12, Res. 22, 24-25, 30-31; Öztaşkın 2018, 618) (Fig. 3-4). Burada farklı olarak, kemer üstündeki testere dişlerinin üst kısımları tuğlalarla oluşturulmuş üçgen alınlık biçimli bir saçak şeklinde tasarlanmıştır. Ancak 'kemer üstü tasarım' yaklaşımı açısından Geç Antikçağ ve aşağıda tanıtılan Laskaris örnekleriyle benzerdir. 


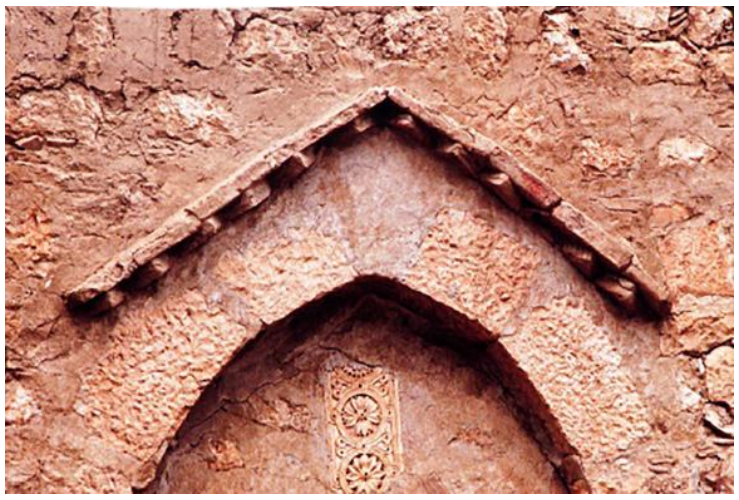

Fig. 3. Myra Alakent Kilisesi, güney pencere (Akyürek 2018, Res. 25)

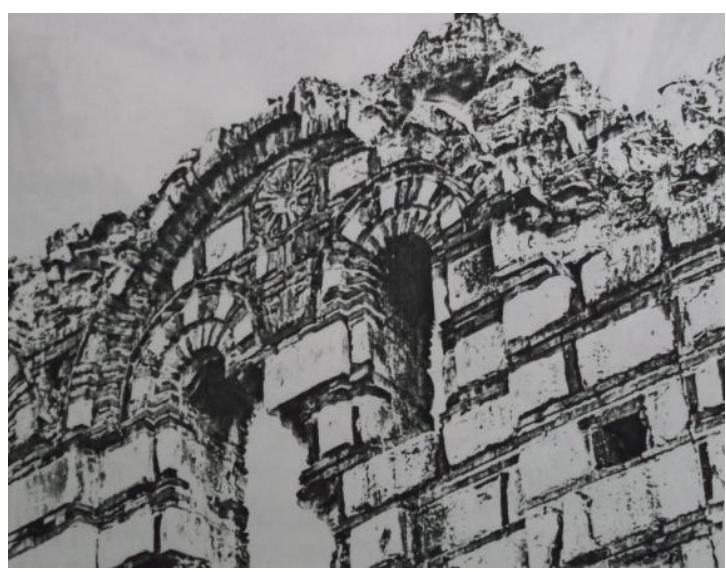

Fig. 5. Bafa Gölü, İkizce Ada, 4 No'lu Kilise, naos kuzey cephesi (Mercangöz 1985, Res. 127)

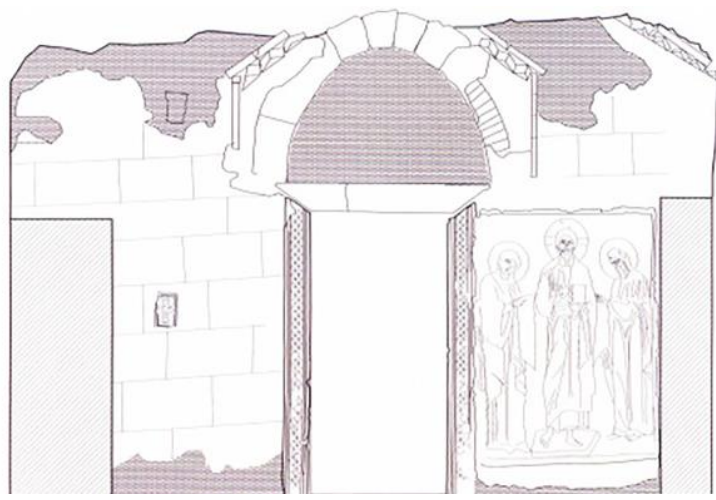

Fig. 4. Myra Alakent Kilisesi, batı cephe (Akyürek 2018, Çiz. 12)

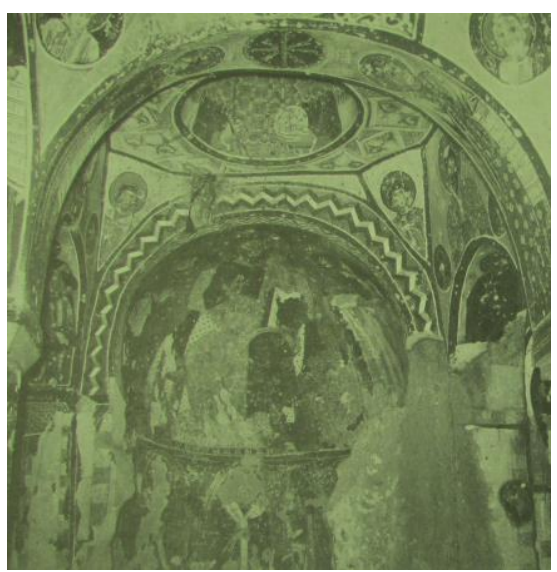

Fig. 6. Elmalı Kilise, apsis (Krautheimer 1981, Res. 360)

Myra'daki yapıdan yak. bir yüzyıl sonra inşa edilen Bafa Gölü’ndeki Laskaris dönemi kiliselerinde, tuğlaların farklı dizilimleriyle oluşturulan cephe hareketlendirmelerinin Anadolu'da yaygınlaşmasıyla birlikte, kemer üstü testere dişi uygulamalarında da bir artış izlenir. 12401255 yılları arasına tarihlenen Bafa Gölü Kahve Hisar Adası'ndaki 8 no'lu Kilise'nin kuzey haç kolundaki alınlık pencerelerinden alttaki iki pencere kemeri ve apsisteki üst pencerelerin kademeli kemerleri ile 1250-1265 yılları arasına tarihlenen Bafa Gölü İkizce adalardan küçüğü üzerinde bulunan 4 no'lu Kilise'nin kuzey cephesindeki pencerelerin kademeli kemerleri testere dişi tuğla şeritle çevrelenmiştir (Mercangöz 1985, 127, 133, 138, 144. Laskarisler mimarisi için ayrica bk. Buchwald 1979, 261-296) (Fig. 5).

Üçüncü çeşitleme içinde ele aldığımız kemer çevresi zikzak süsleme, Anadolu'da pek tercih edilmemiştir; ya da mimaride özellikle fresko ve mozaiklerde uygulandığ 1 için, taş ve tuğla malzemeyle yapılan chevron ve testere dişi örnekler kadar korunamamıştır. Bu çeşitlemenin günümüze ulaşabilmiş en belirgin Anadolu uygulamaları Kapadokya'daki kaya oyma kiliselerden bilinmektedir. Genellikle X-XI. yüzyıllar arasına tarihlenen ve zikzakların çoğunlukla haç kollarının tonoz kemerleri ile apsis kemerlerinde uygulandığ Kilise (Şapel 19), Yılanlı Kilise, Kılıçlar Kilisesi, Çarıklı Kilisesi, Çavuşin Vaftizci Yahya Kilisesi, 12, 27 ve 29b no'lu yapılar sayılabilir (Tarihlendirme ve görseller için bk. Olcay 1990, 22-86, 114 Res. 22, 28, 32, 34, 71, 108-111; Teteriatnikov 1996, Illustr. 8, 11, 16; Moss 2000, 167 pl. 6.20; Curcic 2012, 322;) (Fig. 6). Örneklerin tümünde fresko tekniğinde işlenen zikzaklarda, çoğu zaman farklı renk tonları ve basit çizim teknikleri kullanılarak perspektif sağlanmış, böylece üç boyutluluk elde edilmeye çalışılmıştır. 
Kapadokya örneklerinin benzerlerine, Frigya bölgesindeki iki kaya oyma kilisede de rastlanır. Olasılıkla Orta Doğu Roma dönemine ait Eymir Çiftlik Kilise ve Eyerli Üst/ Yukarı Kilise'de, kemer karınlarına ve alınlarına kırmızı ve siyah boya ile zikzaklar işlenmiştir (Örnekler için bk. Öztaşkın \& Evcim 2010, 42-43, 104; Evcim 2015, 47, 84-85; Evcim 2016, 861-875) (Fig. 7). Her iki örnekte de zikzaklar oldukça basit formdadır ve perspektif kullanılmamıştır

Kapadokya ve Phrygia örnekleri, zikzakların genelde kemerin doğrudan alnına işlenmesiyle, testere dişi uygulamasından ayrılmaktadır.

\section{Anadolu Selçuklu ve Beylikler Dönemi Örnekleri}

Ortaçağ Anadolu-Türk mimarisinin zengin süsleme dağarcığ içinde yer bulan zikzak; testere dişi, chevron ve zikzak olmak üzere üç çeşitleme ile karşımıza çıkar. Testere dişi, pencere ve revak kemerlerini çevreleyen şeritlerde uygulanmıştır. Chevron, Ortaçağ Anadolu'sunda farklı yap1 türlerinde pencere ve kap1 kemerleri ile sütunçelerde görülmektedir. Zikzak ise diğer çeşitlemelerden farklı olarak sıva üzerine fresko tekniğinde işlenmiştir ancak kemerlerde bu uygulamaya rastlanılmamıştır.

Chevronun Ortaçağ Anadolu'sunda kemer taşına işlenmiş ilk uygulamasını 1176-1184 arasında inşa edilmiş olan Artuklu dönemi yapılarından Mardin Sitti Radiviyye (Hatuniye) Medresesi (Altun 1971, 74-78; Bilici 2016, 162, 164) içinde yer alan türbenin mihrabında görmekteyiz (Fig. 8). Kemeri çevreleyen yarım daire formundaki silmelerin hemen üzerinde bulunan chevron, yalnızca kemer alnına kademeli bir şekilde işlenmiştir. Yine yakın tarihlerde inşa edilen Diyarbakır Mesudiye Medresesi’nin (1194-1224) (Baş 2013,

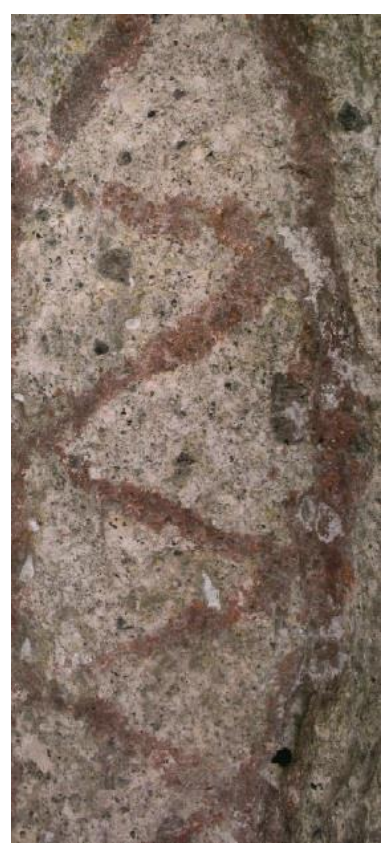

Fig. 7. Frigya, Eyerli Üst Kilise (Öztaşkın - Evcim 2010, 43) 261) avlu batı revakının orta kemeri üzerinde yarım daire silme şeridi ile iç içe geçecek şekilde uygulandığını gördüğümüz bu motifin gerek Mardin'de gerekse Diyarbakır'da form benzerliği ve yarım daire silme şeritleriyle bir arada kullanımı gözlemlenmiştir.

Sadece kemer alnına işlenen fakat kapladığı hacim açısından diğer örneklere göre oldukça küçük boyutta olan Anadolu Selçuklu döneminden bir chevron örneği, Konya'daki Hacı Ferruh Mescidi (1215) (Bilici 2016, 370, 372) ana kapısında karşımıza çıkmaktadır. Motif, burada kemer alnına tek şeritli silmeyle kabartma tekniğinde işlenmiştir. Kitabesi olmamasına karşın bitişiğinde yer alan medreseye göre XIII. yüzyıl başlarına tarihlenen Amasya'daki Halifet Gazi Türbesi (Bilici 2016, 338-339) (Fig. 9) de Hacı Ferruh Mescidi'nde yer alan örneğe benzer bir chevron motifine sahiptir. Burada, chevron kemer alnına biraz daha büyük boyutlu ve çift silme hattına sahip olarak işlenmiş, hemen üstünde bulunan bitkisel bezeme ögesini de yalnız bir cepheden sınırlamıştır. Sahip olduğu kitabelerden anlaşıldığ 1 kadarıyla farklı dönemlerde onarım ve eklemelere tabi olan ve en kapsamlı onarımını Anadolu Selçuklu sultanı I. Alaeddin Keykubad döneminde yaşayan Konya Alaeddin Camii'nin kuzey avlu duvarının dişa bakan yüzündeki bir kitabe nişinde chevron ile karşılaşılır (Fig. 10). Söz konusu motif bu örnekte kemer alnı ile karnına işlenmiştir. Chevron, Konya Alaeddin Camii örneğinde yalnız kemere değil, aynı nişte bulunan sütunçelerin üzerine de uygulanmıştır. Bu durum, yak. sekiz yıl sonra yine I. Alaeddin Keykubad tarafindan Aksaray'da inşa ettirilen Sultan Han'ın avlu taç kapısındaki sütunçe üzerinde yer alan chevron örneğini hatırlatmaktadır (Durukan 2007, 145). Ayrıca Anadolu Selçuklu dönemi eserlerinden Kayseri/Develi'deki Hızır İlyas Türbesi (XIII. yüzyı1 sonu), Konya I. İzzettin Keykavus Kümbeti (1219) ve Konya Sırçalı Medrese (1242-43), 
taçkapılarında yer alan sütunçeler ile Develi Ulu Cami (1281-82) mihrabında yer alan sütunçelerde de chevrona rastlanmaktadır.

Devralmış oldukları mimari kültürü devam ettirmelerinin yanı sıra Anadolu dışı kaynaklı yeni ögeleri de kendi mimarlık ürünleriyle harmanlayarak özgün bir üslup yaratan Beylikler dönemi mimarlığında chevron da bu dönemin süsleme repertuvarına dâhil bir süsleme ögesi olmaya devam etmiştir. Bu bağlamda ilk örneklerimiz Osmanlı Beyliği'nin gerçekleştirdiği mimarlık faaliyetlerinde karşımıza çıkar. Üzerinde yer alan 1417 tarihli onarım kitabesinden 1339-40 yıllarında inşa edildiği anlaşılan Bursa Orhan Gazi Zaviyesi, giriș revakının merkezindeki sivri kemer üzerindeki chevron (Özbek 2002, 40) (Fig. 11) ile Beylikler dönemi mimarisinde kemer üstündeki ilk chevron örneğini sergilemektedir. 1361-1373 yılları arasında inşa edildiği düşünülen Korkuteli Alaeddin Camisinin (Tanman 2005, 217) kuzey cephesinde yer alan eyvan biçimli taç kapısındaki sivri kemerde karşıllaşılan chevron, kemer alnına ve karnına işlenmiştir. Chevronun yapı üzerindeki konumu ve yalnızca kemer alnına işlenmesiyle Bursa Orhan Gazi Zaviyesine en yakın örnek ise Milas Firuz Bey Zaviyesinde görülür (Özbek 2002, 124). Söz konusu yap1 1396 yılında Hacı Firuz Bey tarafından inşa ettirilmiş olup yapının mi-

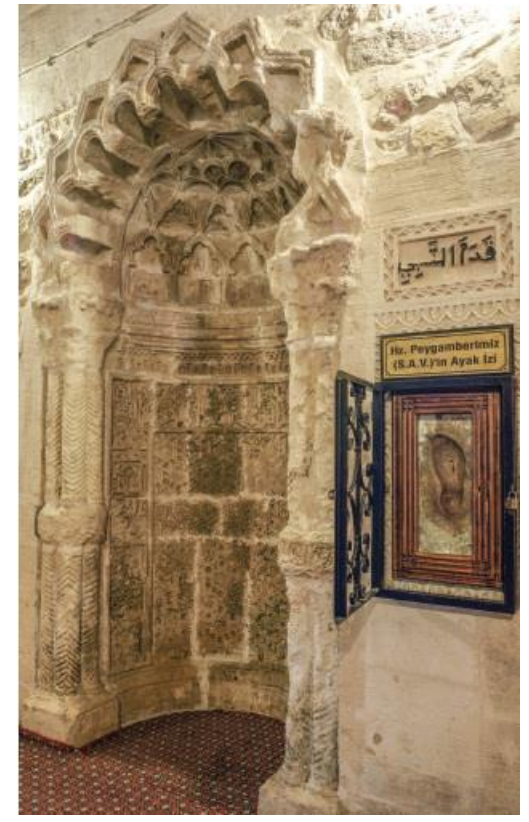

Fig. 8. Mardin Sitti Radviye Medresesi Türbe Mihrabı (Bilici 2017, 162) marı Hasan bin Abdullah'tır. Yapıdaki chevron örnekleri son cemaat yeri revakı merkezinde ve iki yanında yer alan kemerlerin alınlarında gözlemlenir. Firuz Bey Zaviyesi’nden üç-dört yıl sonra inşa edilen Bursa Ulu Camii'nde (1399) de karşımıza çıkan chevron (Fig. 12), uygulama alanı olarak diğer Osmanlı dönemi eserlerinden farklılık göstermektedir. Kuzey cephenin batı yakasında yer alan pencerede gördügümüz bu motif, burada kemer alnını ve karnını saran bir kompozisyon ile işlenmiştir (Özbek 2002, 206). Söz konusu ögeyi diğer Osmanlı yapılarından ayıran bir diğer özellik ise revak kemerine değil, pencere kemerine işlenmiş olmasıdır. Bir başka erken Osmanlı örneği olarak Anadolu coğrafyası dışında 1420 yılına ait Dimetoka Çelebi Mehmet Camii taç kapısında da chevron ile karşılaşılır (Çam 2000, 32).

Erken Osmanlı dönemi eserleri arasında chevronla birlikte gördüğümüz bir diğer çeşitlememiz ise testere dişidir. Söz konusu form bu dönemde farklı yapı gruplarında pencere ve revak kemerlerini çevreleyen şeritlerde uygulanmıştır. Örneklerimizin yoğunluğunu ise Bursa'daki eserler oluşturur. Pencere kemerlerini çevreleyen testere dişi şeridine Bursa'da Orhan Gazi Zaviyesi (1339-40), I. Murat Hüdavendigar Cami-Medresesi (1366 civarı), Selçuk Hatun Cami (15. yüzyıl) (Fig. 13), Hamzabey Cami (1477), Muradiye Medresesi (15. yüzyıl), Yıldırım Bayezid Darüşşifası (1390-94), Amasya'da Bayezid Paşa Cami (1414) (Fig. 14) ve Osmancık'ta Koca Mehmet Paşa Cami'nde (1431) rastlanmaktadır. Testere dişinin kemerlerdeki örnekleri olarak Yenişehir Seyyid Mehmed Dede Zaviyesi (1363), Bursa'daki Yıldırım Bayezid Darüşşifas1, Orhan Gazi Zaviyesi, Cariyeler Türbesi (15. yüzy1l) ve Muradiye Cami (1425-26) verilebilir. Burada dikkat çeken bir örnek olarak Amasya Bayezid Paşa Cami'ndeki testere dişi şeridine değinebiliriz. Erken Osmanlı mimarisinde yukarıda sıraladığımız testere dişi çeşitlemesi örneklerinin hepsinde tuğlalar bir önceki başlıkta değerlendirdiğimiz Doğu Roma dönemi örneklerine teknik açıdan uyum sağlamaktadır. Ancak Amasya Bayezid Paşa Cami'ndeki uygulamada tuğlaların diziliminde farklılık görülür. Pek çok örnekte tuğlaların 45 derecelik açıyla tam olarak yatay gelecek biçimde örüldügü görülürken, burada tuğla uçları belli bir açıda 
yukarıya kaydırılarak chevrona yaklaşan bir görünüm elde edilmiştir.

Batı Anadolu'da inşa tarihleri bilinen chevrona sahip yapıların yanı sıra, tarihleri tam olarak tespit edilemeyen ve XIII. yüzyıl ile 16. yüzyıl arasına atfedilen Güney ve Doğu Anadolu coğrafyasındaki bir grup yapıda da chevron tespit edilmiştir. Kronolojik sıraya göre ilk olarak Antakya'daki Meydan Hamamı'ndan bahsedebiliriz. (Fig. 15). F. Şanc1 (2006, 342), eserin giriş kapısı kemerinde bulunan chevronu odağına alarak tarihlendirmeye çalıştığı Meydan Hamamı'nı, yukarıda değindiğimiz bir kısım Osmanlı Beyliği dönemi yapılarıyla karşılaştıra-

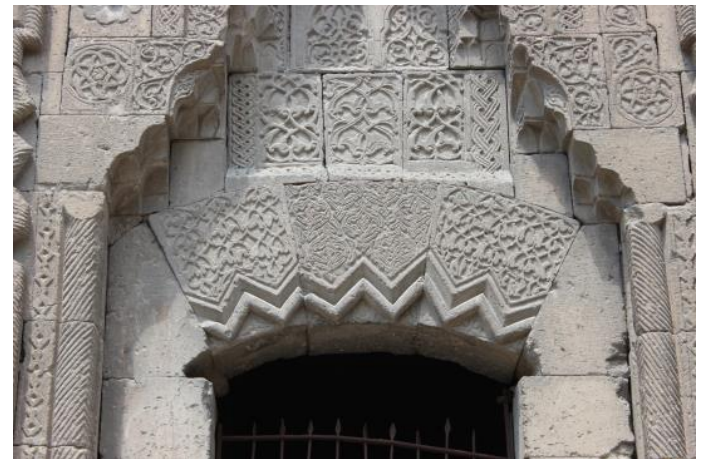

Fig. 9. Amasya Halifet Gazi Türbesi Taçkapısı). rak XIII. yüzyıl sonu ile 14. yüzyılın başlarına tarihlemektedir. Bu örnekte kemer alnına ve karnına işlenmiş olan chevron, Bursa Ulu Camii penceresinde bulunan motife yakın bir kompozisyona sahiptir. Kitabeye sahip olmayan fakat süsleme ve plan özellikleriyle 14. yüzyıl sonu15. yüzyıl başına tarihlenen Hasankeyf'teki Kızlar Camii, kuzey cephesinde yer alan pencere kemerinde chevron motifine sahiptir (Yurttaş 1991, 151). Akkoyunlu hükümdarı Sultan Kasım döneminde inşa edilmiş olan Mardin Sultan Kasım Medresesi'nde, ana eyvanın her iki yanında yer alan sivri kemerli kapılarda chevrona rastlanır (Gündoğdu 2002, 161). Bu yapıdaki örnek yine kemer alnına ve karnına işlenmiştir. 1513 ile 1541 yılları arasında farklı inşa aşamaları geçiren Ramazanoğulları'na ait Adana Ulu Camii, yapı bütünüyle Mısır-Suriye-Anadolu sentezini en iyi yansıtan örnekler arasında yerini almıştır. Süsleme ögelerinin bu denli çeşitliliğini gördüğümüz yapıda chevron ile de karşılaşılır. Yapının ilk inşa aşamasına ait olduğu düşünülen kuzeybatı köşedeki kütle (Uysal 1985, 279), dışta sivri kemerli bir nişe sahip olup söz konusu sivri kemerin alnında ve karnında chevron yer almaktadır. Yine aynı bölge içinde yer alan Dulkadirli Beyliği'ne ait Maraş Taş Medrese'ye bitişik türbenin sivri kemerli kapısında da chevron bulunur (Bayburtlu-

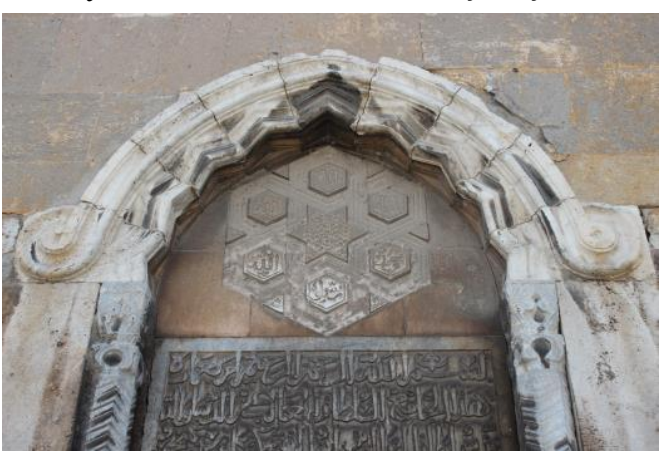

Fig. 10. Konya Alaeddin Cami Kuzey Avlu Cephesi Kitabe Nişi

oğlu 1973, 248) (Fig. 16). Bursa Ulu Camii, Adana Ulu Camii, Mardin Sultan Kasim Medresesi, Antakya Meydan Hamamı ve Hasankeyf Kızlar Cami'nin sahip olduğu chevron gibi kemer alnına ve karnına kalın silme hatları oluşturacak şekilde işlenmiş olan söz konusu türbedeki motif, incelediğimiz dönem kapsamında Anadolu coğrafyasında karşılaştığımız en geç örnektir. Türbenin inşa tarihi kesin olarak bilinmese de H. Gündoğdu yapının 16. yüzyıl başlarında yapılmış olabileceğini ileri sürmektedir (Gündoğdu 1986, 58). 16. yüzyılda Anadolu dış1 örnekler olarak Kudüs'teki Bab al-Silsila, Bab al-Atm ve Birkat al-Sultan adlı sebillerin kemerlerinde de chevron motifine rastlanmaktadır (Yenişehirlioğlu 1989, 50-51).

Üçüncü çeşitleme olarak tanımladığımız zikzağın, kemer ve çevresinde örneğine rastlanmamıştır. Günümüze ulaşabilen eserler arasında ise bu süsleme, yapıların beden duvarına işlenmiş olup birkaç örnekle sınırlıdır. Anadolu Selçuklu sultanı Alaeddin Keykubad'ın 1221-1223 tarihleri arasında yaptırdığı Alanya İç Kale Sarayı'nın iç mekân duvar fresklerinde kırmızı ve beyaz renkte zikzak motifine rastlamaktayız (Arık 2017, 130, 133). 
XIII. yüzyılın ilk yarısına tarihlenen Alanya'daki Hasbahçe Köşkü’nün duvarlarında sıva üzerine işlenmiş kırmızı ve beyaz renklere sahip zikzak yine in situ olarak günümüze ulaşabilmiştir (Yavaş 2000, 111; Bilici 2016, 246-247). Aynı bölgede bulunan ve üzerinde yer alan freskler neticesinde Anadolu Selçuklu dönemine tarihlenen Çıplaklı Köyü'ndeki yapı, sıva üzerine fresk olarak işlenmiş kırmızı renkte zikzağa sahiptir (Yavaş 2000, 82-83). Benzer bir örnek yine aynı bölgedeki Gülefşen Köşkü'nde bulunur.

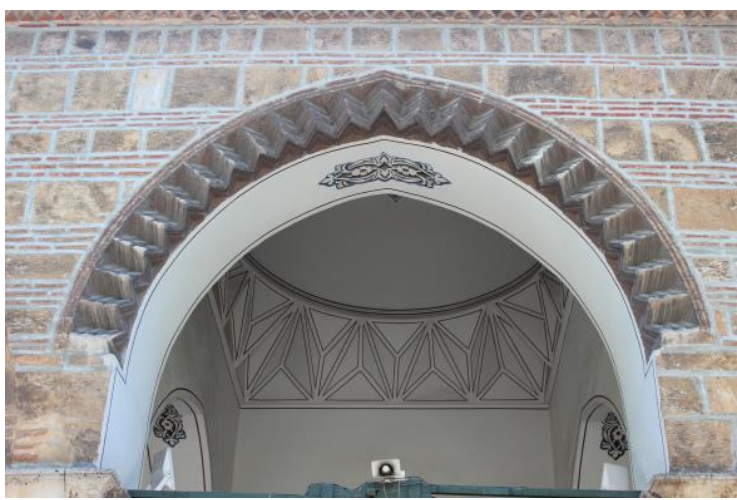

Fig. 11. Bursa Orhan Gazi Zaviyesi Revak Kemeri Fresk olarak işlenmiş zikzak, Çıplaklı Köyü örneğindeki gibi kırmızı renge sahiptir (Yavaş 2000, 95). Yukarıda sıraladığımız söz konusu zikzak örneklerinin ortak yönleri (Alanya İç Kale'deki örnek haricinde) cephelere fresk olarak işlenmesidir. Bir önceki başlık altında değerlendirdiğimiz kaya oyma kiliselerdeki kemer çevresine işlenmiş zikzakları, Anadolu Selçuklu mimarisinin mevcut örnekleri ışığında yalnızca cephelerde görmekteyiz.

\section{Anadolu, Ortadoğu ve Avrupa'da Tarihsel Süreç ve Etkileşim}

Yazının bu kısmında, mimarideki söz konusu kemer ve çevresi zikzak süslemesinin Avrupa ve Orta Doğu'daki tarihsel gelişim süreci, sirasiyla zikzak, testere dişi ve chevron terimleriyle yine üç farklı çeşitleme kapsamında incelenerek, Anadolu coğrafyasıyla olan olası etkileşimleri değerlendirilecektir. Bu şekilde, günümüze ulaşabilmiş örneklerinin büyük bir kısmı Ortaçağ'dan bilinen bu motifin, kemer ve çevresi erken gelişim süreci irdelenebilecektir.

Zikzak çeşitlemesi kapsamında ele aldığımız uygulamanın erken örnekleri Roma İmparatorluk Dönemi'nden bilinmektedir. Örneğin Herculaneum'daki Neptün ve Amphitrite Evi'ndeki bir duvar mozaiğinde figürleri çerçeveleyen nişin kemer alnı, üç boyutlu etki sağlanarak zikzak motifleriyle hareketlendirilmiştir (Moss 2000, 165-166). Öte yandan Frigya ve özellikle de Kapadokya bölgesinden bildiğimiz Orta Doğu Roma dönemi kemer karnı ve alnı boyalı zikzak uygulamalarının üslup açısından yakın erken örnekleri, Orta Doğu ve Avrupa'da Geç Antikçağ'dan itibaren takip edilebilmektedir. VI. yüzyıla ait Mısır Bavi'deki Aziz Ioannes

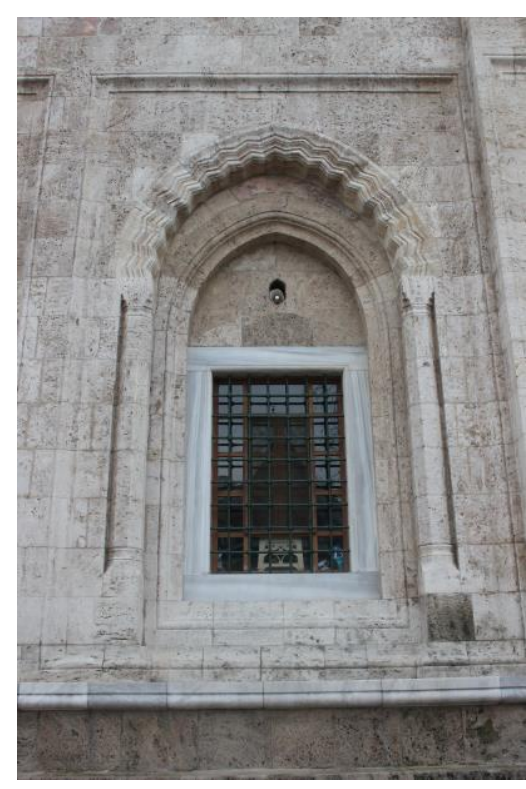

Fig. 12. Bursa Ulu Cami Kuzeybat1 Cephe Pencere Kemeri Koptik Manastırı'nda bulunan bir kemerin alnına fresko tekniğiyle üç farklı renkte zikzaklar işlenmiştir. Yine aynı ülkenin Sakkara sınırları içinde yer alan VI-VII. yüzyıllara ait Aziz Jeremias Koptik Manastırı'nın 1725 numaralı hücresinde bulunan nişin kemeri çevresine fresko tekniğinde zikzaklar uygulanmıştır (Moss 2000, 166). Orta Doğu ve Avrupa kökenli el yazmalarındaki minyatürlerde de kemer üstü zikzak süslemeleri Geç Antikçağ'dan Ortaçağ'ın en erken XIII. yüzyıllarına kadar uygulanmaya devam etmiştir. Bu dolaylı örnekler, konumuzla ilişkili olan mimari kurguya işaret etmeleri açısından önemlidir. Örneğin VI. yüzyıla ait Suriye Rabbula İncillerindeki arkadlarda zikzak benzeri desenlere rastlanır. VI. yüzyıla ait diğer bir el yazması Aziz Augustine İncili'ndeki Aziz Luka tasviri ise zikzakla çevrelenmiş bir kemer içinde verilmiştir (Moss 2000, 163-164). Her iki örnek de açık bir şekilde mimari düzen içinde 
verilmişken, üç boyutlu plastik etki pek izlenmez. Bu etkinin kısıtlılığı, yukarıda verilen Mısır'daki fresko örnekleri için de geçerlidir.

Zikzak motifinin Ortaçağ örnekleri, Geç Antikçă̆'a kıyasla oldukça fazladır ve aşağıda tartışılacağı üzere bu açıdan testere dişi ve chevron uygulamalarıla benzer bir kronolojik gelişme sergilemektedir. Dolayısıyla üç çeşitleme de farklı üslup ve alanlarda fakat benzer kompozisyonlarda tasarlanan zikzak motifinin kemer ve çevresinde Ortaçağ boyunca yaygın kullanılan bir motif haline geldiğini göstermektedir.

Anadolu Ortaçağ'ına ait X-XI. yüzyıldan Kapadokya örnekleri ile Frigya'daki Orta Doğu

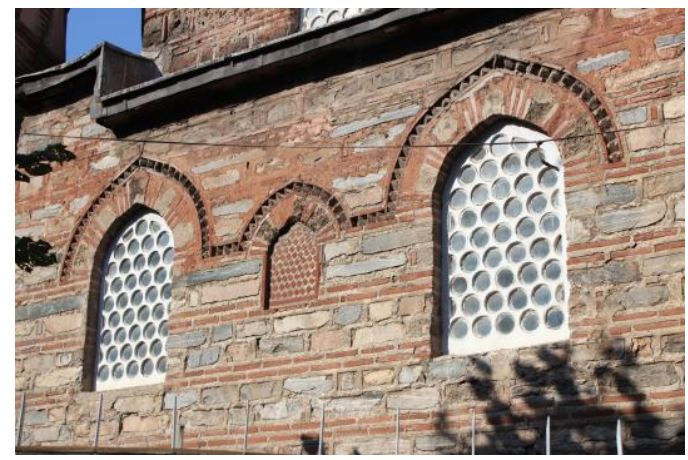

Fig. 13. Bursa Selçuk Hatun Camii Kuzeybatı Cephe Pencereleri

Roma dönemi örnekleri yukarıda tanıtılmıştı. Benzer uygulamalara Avrupa, Balkanlar ve Kıbrıs'ta da rastlanır. Kıbrıs'taki Pera Chorio'daki, olasılıkla XII. yüzyıla ait Kutsal Havariler Kilisesi'nin apsis kemer alnı, fresko tekniğinde zikzaklarla bezenmiştir (Megaw \& Hawkins 1962, 280 fig. 2). Yakın tarih ve üsluptaki bir diğer örnek, Makedonya Kurbinovo'daki 1191 tarihli Aziz Georgios Kilisesi'dir. Yine fresko tekniğinde ve apsis kemer alnında zikzak motifi yer alır (Curcic 2012, 322 fig. 11.14). Mimarideki bu uygulamalar Doğu Roma'nın Geç Ortaçağ'ına kadar devam eder: Sırbistan'daki (Günümüzde Kosova) Pec Manastırı'nda yer alan Tanrı Anası Kilise'nin (1324-1337) kubbe kasnağındaki pencerelerin cepheye bakan kemer alınları, fresko tekniğinde zikzaklarla hareketlendirilmiştir (Curcic 2012, 328- 329 fig. 11.22). Sırbistan'daki kiliseden kısa bir süre önce geniş çaplı bir onarım ve yenileme çalışması geçiren (yak. 1315/16-1320 arası) Konstantinopolis’teki Kariye Kilisesi’nin aynı döneme ait dış nartheks ve parakklesion bölümlerindeki tonoz ve kubbe kemerlerinde, fresko tekniğinde uygulanmış zikzaklar birtakım ikonografik sahneleri sınırlamaktadır (Akyürek 1996, 43; Ousterhout $2002,12,14,55-57,71,73-75)$.

Zikzakların minyatürlerde mimari kompozisyon düzeni içinde verilmesi, Ortaçağ boyunca devam etmiştir. Bunlar içinde en nitelikli örnekler arasında Kilise Kanun Tablolarındaki minyatürler sayılabilir. Her ikisi de XIII. yüzyılın ikinci yarısına ait İncil minyatürlerinde resmedilen kemerlerin alınları zikzaklarla işlenmiştir (Curcic 2012, 318-319).

Zikzak çeşitlemesinin mimaride kemer ve çevresi fresko bezemeleri ile minyatürlerdeki dolaylı mimari kompozisyon temelli örnekleri incelendiğinde, Geç Antikçağ uygulamalarında mimari plastik etkisi yaratan perspektif tekniklerinin genelde kullanılmadığ 1 ve zikzakların kemere yüzeysel işlendiği izlenmektedir. Günümüze çok sayıda örneği ulaşabilen Ortaçağ eserlerinde ise motifte belirgin bir şekilde plastik etkinin arttığ renk kullanımı ve ışık-gölge gibi yanılsama tekniklerinin geliştiği; dolayısıyla mimarideki chevron ve testere dişi uygulamalarına yaklaştığı söylenebilir. Bu genelleme birçoğunda zengin fresko teknikli duvar resimlerini barındıran Ortaçağ Kapadokya kaya kiliseleri açısından büyük oranda geçerliyken, çoğunda fresko izine dahi rastlanamayan Frigya'daki zikzaklar için tam aksine bir durum sergilemektedir. Dolayısıyla Ortaçağ'daki söz konusu belirgin değişimlerin gelenekler bağlantılı istisnaları da içerebileceği dikkate alınmalıdır. 
İki boyutlu zikzak çeşitlemesinin Ortaçağ'da bu denli gelişme göstermesi ve üç boyutlu bir görünüme sahip olması, chevron ve testere dişi motiflerinin mimaride yine aynı dönemde yaygınlaşmasıyla açıklanabilir. Diğer bir ifadeyle, el yazması ve freskolardaki kemer ve çevresi zikzak motifinin ilham kaynağı olarak yorumlayabileceğimiz gerçek mimari örnekleri Ortaçağ içinde arttıkça, söz konusu iki boyutlu örnekler de bir nevi taklit yoluyla gelişme göstermiş olmalıdır.

Zikzak çeşitlemesiyle benzer bir tarihsel süreç gösteren testere dişi bezemenin Geç Antikçağ' da İtalya'daki bazı yapılarda saçaklık kısımlarında bazı örnekleri bilinse de (Krautheimer 1981, 436; Öztaşkın \& Öztaşkın 2012, 332) kemer ve çevresi uygulamalarının erkenleri, bildiğimiz kadarıyla Geç Antikçağ'a ait söz konusu iki Anadolu örneğidir. Bu örnekler, sonrasındaki yüzyıllarda testere dişi, zikzak ve chevron çeşitlemelerindeki benzer tarihsel boşluğu paylaşır, en geç $X$. yüzyıldan itibaren

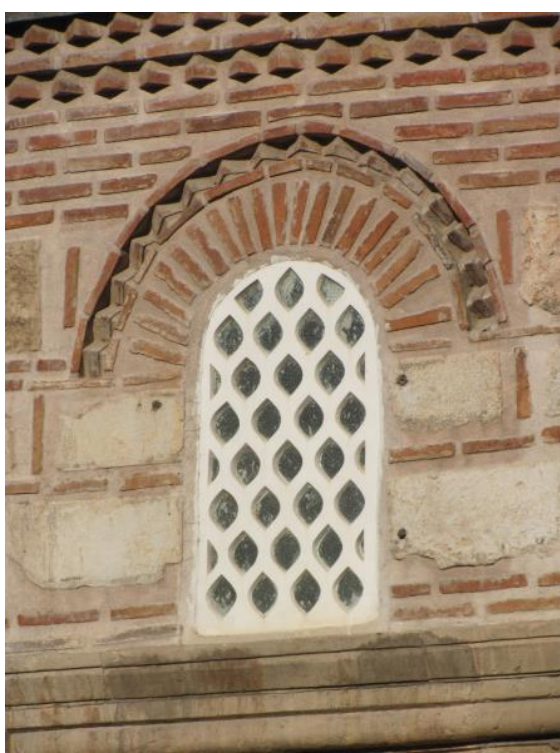

Fig. 14. Amasya Bayezid Paşa Cami özellikle Yunanistan'daki Orta Doğu Roma Dönemi kiliseleriyle birlikte tekrardan belirir ve Ortaçağ' $ı$ sonlarına kadar en yaygın kullanım dönemini yaşar. Motifin bu dönemde cephelerdeki pencere kemer ve çevresinde geniş çaplı kullanıldığ 1 erken örneklerinden biri, şüphesiz Hosios Loukas Manastırı'nın X. yüzyıla ait (946- 955 ?) Theotokos Kilisesi'dir (Krautheimer 1981, 406-407; Moss 2000, 160; Curcic 2012, 321 fig. 11.13). Örnekler, bu yüzy1ldan sonra Yunanistan'da oldukça yaygınlaşır ve olasılıkla bir moda olarak çevre bölgelere yayılır. Bunların karakteristik Orta Doğu Roma örnekleri arasında, aynı manastırın XI. yüzyılın başlarında inşa edilen katholikonu (Krautheimer 1981, 406; Mango 2006, 177, 180), Atina'daki H. Theodoroi Kilisesi (yak. 1060- 1070) (Krautheimer 1981, 413), Daphni'deki manastırın katholikonu (yak. 1080) (Krautheimer 1981, 416; Mango 2006, 184) ve Kastoria'daki Panagia Kumbelidiki Kilisesi (XI. yüzyı1) (Mercangöz 1995, Res. 5); Geç Doğu Roma örnekleri içinde ise Khios (Sakız Adas1) Krina'daki Panaghia Kilisesi (yak. 1225-1240/ Laskarisler) (Buchwald 1979, 274-276 Fig. 20), Arta'daki Parigoritissa Kilisesi (1282-1289) ile olasılıkla XIII. yüzyıla ait H. Basilios Kilisesi (Krautheimer 1981, 452; Mango 2006, Fig. 222), Ohrid'deki Sv. Kliment Kilisesi (1294/95) (Krautheimer 1981, Fig. 382-383) ve Mistra'daki H. Theodoroi Kilisesi (1290-96) (Krautheimer 1981, Fig. 384) sayılabilir. Testere dişi motifi, bu örneklerin tümünde dış cephe hareketlendirmesi kompozisyonu kapsamında pencere, kör kemer ve niş kemerlerinde uygulanmıştır.

Kemer çevresi testere dişi motifi Doğu Roma dışındaki Avrupa topraklarında da yer yer uygulanmıştır. Moss, XI. yüzyıl içinde "İlk Romanesk" olarak adlandırılan İspanya ve Lombardiya yapılarında bu bezemenin popüler olduğunu aktarır. Örneğin İtalya'nın Emila-Romagna bölgesinde bulunan Pomposa Manastırı'nın XI. yüzyıla ait çan kulesinin cephesindeki bazı kemerler, Orta ve Geç Doğu Roma örneklerine benzer şekilde tuğladan testere dişiyle süslenmiştir (Moss 2000, 160). Diğer bir örnekle, Doğu Roma'nın yakın temaslarının bulunduğu Venediklilerin lagününde karşılaşılır. Murano Adası üzerinde bulunan XII. yüzyıla ait Maria e Donato Kilisesi'nin doğu cephesindeki pencere kemerinin üst kısmı testere dişi ile çevrelenmiştir (Curcic 2012, 328-329 fig. 11.22). 
Avrupa'nın Anadolu ile etkileşimde bulunduğu Konstantinopolis topraklarındaki Doğu Roma dönemi kiliselerinde de testere dişi süslemesinin cephede kullanımı Yunanistan'da yaygınlaşmaya başladığı $\mathrm{X}$. yüzyıl ile birlikte görülmeye başlar. Krautheimer, bu kentteki kiliselerde Yunanistan'dan farklı olarak testere dişinin sadece kubbe kasnağında kullanıldığını gözlemlemiştir (Krautheimer 1981, 402). Myrelaion Kilisesi (yak. 920) (Krautheimer 1981, Fig. 311, 380; Freely \& Çakmak 2017, Res. XXIV), Pantepoptes İsa Kilisesi (1081-1087) (Krautheimer 1981, Fig. 315), Kariye Kilisesi (XI. yüzyıl sonu-XII. yüzyıl başındaki evresi) (Freely \& Çakmak 2017, Res. XLVI. Tarihçe için bk.

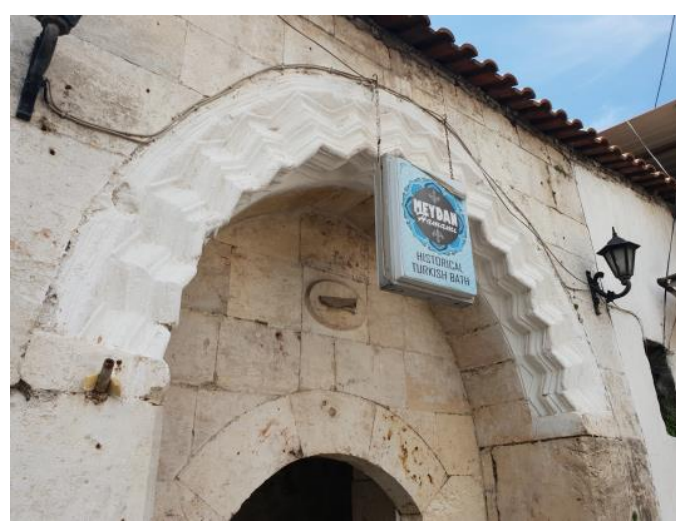

Fig. 15. Antakya Meydan Hamamı Ana Kapısındaki Chevron Motifi Ousterhout 2002, 11-12; Klein et al. 2007, 17-19), Kilise Camii (XII. yüzyıl evresi) (Freely \& Çakmak 2017, 172 Res. XXIII) ve Theotokos Pammakaristos Kilisesi Güney Şapeli (14. yüzy1l baş1) (Freely \& Çakmak 2017, 217-222 Res. XLII) cephelerinde bu uygulama açıkça izlenebilmektedir. $\mathrm{Bu}$ örneklerde testere dişi tuğla şeritler Krautheimer'in belirttiği gibi saçaklarda kullanılmasına rağmen, bezemenin kasnak pencerelerinin hemen üst kısımlarında bulunarak kemerleri vurgulaması, söz konusu kemer üstü uygulamasını kısmen anımsatmaktadır. Üstelik 19. yüzyıla ait iki kilise tasviri, doğrudan kemer alnı uygulamasının kentteki varlığını da gösterir: Myrelaion Kilisesi'nin yak. 1876 yılına ait tasvirinde, haç kollarından birisinin cephesinde bulunan (kör?) kemerin üst kısmının testere dişi bezeme ile hareketlendirildiği seçilebilmektedir (Freely \& Çakmak 2017, Res. 89). Kariye Kilisesi'nin ise 1877 yılından kalma tasvirinde, 14. yüzyıldaki Metokhites yenileme dönemine ait (yak. 1315/16-1320 aras1) dış nartheksin batı cepheye bakan kademeli tonoz kemerlerinin üst seviyelerinin testere dişleri ile bezendiği görülür. Ancak bunlar 1875-76 restorasyonunda ortadan kalkmıştır (Klein et al. 2007, 26, 122 Res. 15). Tüm bu günümüze ulaşabilmiş örnekler, tartıştığımız uygulamanın Konstantinopolis'te de kullanıldığını gösterse de Yunanistan'daki yaygınlığına ve çeşitlemelerine yaklaşamadığına işaret etmektedir.

Yukarıda bahsedildiği üzere Doğu Roma'da yaygın kullanım alanı bulan testere dişi tuğla süsleme Anadolu'da Erken Osmanlı dönemindeki yapıların kemer ve çevresinde uygulanarak İslam mimarisine dâhil edilmiş, ilerleyen yüzyıllarda Osmanlı'nın Avrupa'daki Balkan topraklarında da tercih edilmeyi sürdürmüştür. Bu uygulama şüphesiz, ortak coğrafyada üretilmiş olan Doğu Roma mimarisi süsleme dağarcığından esinlenerek Osmanlı mimarisine katılmıştır. Testere dişinin gerek erken örneklerinin coğrafi yayılımları, gerekse de Osmanlıların yine beylikler döneminde Doğu Roma mimarisi cephe hareketlendirme ögelerinden kendi mimarisine dâhil ettiği diğer unsurlar, söz konusu etkileşim önerisini akla yatkın kılmaktadır.

Mimari süsleme ögesi olarak chevron, Ortaçağ boyunca Anadolu, Ortadoğu ve Avrupa coğrafyasında yaygın bir şekilde uygulanmıştır. Bununla birlikte chevronun kökeni ve yayılım rotasına ilişkin derin bir belirsizliğin olduğunu dile getirmekte fayda vardır. Her ne kadar bu rota hakkında farklı görüşler ortaya atılmışsa da köken konusunda verilen ilk örnek, 712-715 yılları arasında Emevi halifesi I. Velid zamanında inşa edilen Kuseyr Amra'nın kubbeli odasında Zodyak betimlemesine sahip kubbenin eteğini baştan başa dolanan çift sıralı chevron olmaktadır. 
Öte yandan, 705-710 yılları arasına tarihlenen ve yine I. Velid zamanında inşası tamamlanan Kasrü'l Haranah'ın iç mekân kapı kemerlerini çevreleyen chevron, mimari bezeme olarak kemerde görülen ilk chevron örneğini oluşturmaktadir (Enderlein 2007, 73). Bununla birlikte Haranah'a benzer bir örnek, bu tasarımın henüz V. yüzyılda Suriye coğrafyasinda uygulandığını gösterir. Suriye'deki Aziz Simon Stilit manastır kilisesinin yuvarlak kemerli pencere açıklıklarından gördüğümüz zikzak ile Haranah'taki örnek arasında form ve kullanım alanı açısından benzerlikler vardır. Henüz Suriye'de V. yüzyılda kemer çevresi uygulamasıyla karş1mıza çıkan bu form, genel kabul olan ilk kullanım dönemini (VIII. yüzy1l) V. yüzyıla kadar çeker. Yine, Creswell'in Brisch'den alıntı yaparak sunduğu, Emevi Kasrı Jabal Says'in avlu revak kemerleri alınlarında da bulunan chevron (Creswell 1979, 475) ile 726 yılında Emevi halifesi Hişam b. Abdülmelik döneminde son halini alan Kayravan Ulu Camisinin mihrap önü kubbesini taşıyan kemerde uygulanan chevron, Kasrü'l Haranah ile birlikte Ortadoğu'da kemerde görülen İslam dönemi ilk chevron örneklerini temsil eder. Abbasi döneminde Nil Nehri'nin debisini ölçmek amaciyla 861 yılında inşa edilen Roda Adası'ndaki Nilometre (Creswell 1979, Pl. 81) binasinda bir kapı kemeri üzerinde yer alan kırık çizgiler de chevron olarak değerlendirilebilir. VIII. ve IX. yüzylllarda bugünkü Ürdün ve Mısır topraklarında ilk örneklerine rastladığımız chevronun sonraki uygulamaların ise XI. yüzyılda İtalya'da görmekteyiz. S. Maria Maggiore Kilisesi (1036) (Fig. 17) ve S. Clemente di Casauria Kilisesi (1176-1182) ana kap1 kemerinde karşılaştı̆̆ımız chevron (Ricci 1925, 136, 181), çok kısa bir zaman içerisinde neredeyse tüm Avrupa'ya yayılacak, Macaristan'dan (Szent György Kilisesi - 1256) (Kubach 1975, 326-27) Almanya'ya (Worms Katedrali 1181 öncesi) (Kaffenberger 2017, 165) ve Britanya'ya (Durham Katedrali - 1110-1120) (Moss 2000, 113, 153) kadar Ortaçağ sonlarına değin yaygın bir biçimde süsleme ögesi olarak tercih edilecektir. Chevron üzerine yapılan

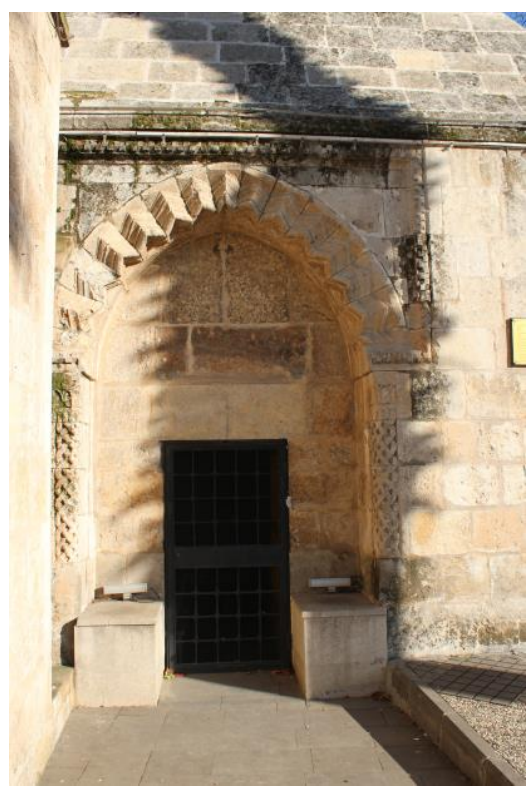

Fig. 16. Maraş Taş Medrese Türbesi Taçkapısı

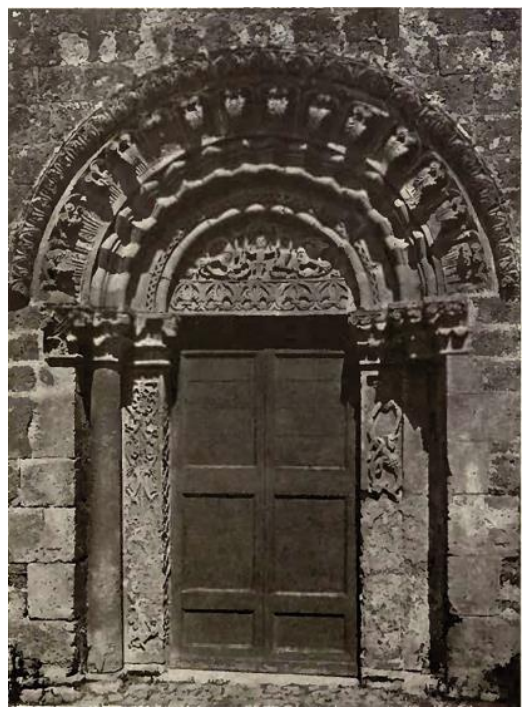

Fig. 17. S. Maria Maggiore Kilisesi (Ricci 1925, 136) çalışmalarda bu motifin Avrupa'ya nasıl intikal ettiği, ilk örneklerinin Ortadoğu'da olmasına karşın yak. 200 yıl sonra Avrupa'da nasıl ortaya çıktığı halen tartışılan bir konudur. Bu problemin çözümü, İslam topraklarında IX. ile XI. yüzyıl arasındaki süreçten ortaya çıkarılacak olası chevron örneklerinin tespiti ile mümkün olabilir.

Chevronun Ortadoğu'da yeniden canlanış sürecinin XI. yüzyıl sonlarında başlayan Haçlı seferlerinin hemen sonrasında, bölgeye yerleşen ve çeşitli kentleri ele geçirip prenslikler kuran Avrupalıların inşa faaliyetleriyle başladığı yönünde kanıtlar mevcuttur. Beyrut'taki Latin Katedrali (1150 öncesi), Kudüs St. Anne Kilisesi (1130-40), Nablus'ta bu dönemde inşa edilmiş olan kiliselerden çevrilen An Nasr ve Al-Khadra camileri ile Biblos'taki St. John Katedrali'nin baldaken planlı vaftizhanesinin kemerlerinde yer alan chevron, Haçlı döneminde uygulanan söz konusu motife örnek olarak gösterilebilir (Kaffenberger 2017, 166). Bununla birlikte Haçlıların 
hâkimiyetini kaybettiği bazı kentlerde inşa edilmiş olan camilerin sahip oldukları chevron motiflerinin de yine Haçlı dönemi eserlerinden devşirildiği düşünülmektedir (Salam-Liebich 1983, 25; Kaffenberger 2017, 167-168). İslam ülkelerinin bölgeye tekrar hâkim olmalarının ardından chevron motifinin uygulanmasına devam edildiği görülmektedir. Özellikle Eyyübi ve Memlûk dönemi mimarlığında kullanılmaya devam eden chevron, farklı yapı türlerinde karşımıza çıkar. Söz konusu dönemde chevrona rastlanan yapılara örnek olarak Halep Meşhed el-Hüseyin (kemer alnı ve karnına - 1173) (Eser 2000, 75), Mescid-i Aksa Cami Kuzey Cephe Revak kemeri (kemer alnı ve karnına - 1218-19) (Buhl 1977, 961; Hillenbrand 2015, 233), Kahire Sultan Baybars Cami taçkapısı (kemer alnı ve karnına - 1266-69) (Behrens-Abouseif 1989, 94) (Fig. 18), Trablus'taki Menzil Han1 (kemer aln1 ve karnına - 1309) (Fig. 19) ve Kartaviya Medresesi taçkapısı (kemer alnı ve karnına - 1316-26) (Salam-Liebich 1983, 16, 18, 115, 170-171) verilebilir.

Yukarıda siralanan Ortadoğu örneklerinin Anadolu coğrafyasına etkisiyle ilgili elimizde birtakım kanıtlar bulunmaktadır. Mardin Sitti Radviyye Medresesi'nde (11761184) ve Diyarbakır Mesudiye Medresesi'nde (1194-1224) uygulanan chevronun, yarım daire silme hattıla oluşturduğu kompozisyon ile Halep Mehşed el-Hüseyin'deki (1173) chevronun benzer karakterde olması, söz konusu uygulamanın Anadolu'ya Suriye'den aktarılmış olabileceğini düşündürmektedir. Anadolu-Suriye etkileşimini chevron üzerinden değerlendirmeye olanak tanıyan diğer örnekleri Anadolu Selçuklu mimarisinde görmekteyiz. Şamlı (D1mışk) mimar Muhammed bin Havlan tarafindan inşa edilen Konya Alaeddin Camii kuzey cephesinde malzeme kullanımı ve süsleme ögelerine bakıldığında Suriye etkisi açıkça izlenmektedir. Burada yapı kitabesinin yer aldı ̆̆ 1 nişin kemerinde uygulanan chevronun kaynağ 1 , yapı mimarının Şamlı olması dolayısıyla Suriye'ye kuşkusuz bir biçimde bağlanabilir. Chevronun Beylikler dönemindeki uygulamalarına baktığımızda yine Ortadoğu etkisiyle karşılaşırız. Bursa Orhan Gazi Zaviyesi ve Milas Hacı Firuz Bey Zaviyesi (1396) revak kemerlerinin merkezinde konumlanan chevron motifi, yalnızca kemer alnına işlenen haliyle Kahire Sultan Baybars Camii (1269) kuzeydoğu taçkapısı, Kudüs Barka Han Türbesi (1264-80) ana kapı kemeri ve Yubna Ebu Hureyre Meşhedi (1274) revak kemeri gibi bazı Memlûk yapılarında da karşımıza çıkmaktadır (BehrensAbouseif 1989, 94; Tanman 2000, 85). Bursa Ulu Cami (1399) kuzey cephe pencere kemerinde görülen chevron, hem revak kemeri yerine pencere kemerine hem de kemer alnına ve karnına işlenmiş haliyle Orhan Gazi ve Hacı Firuz Bey zaviyelerinde bulunan chevron örneklerinden ayrılır.

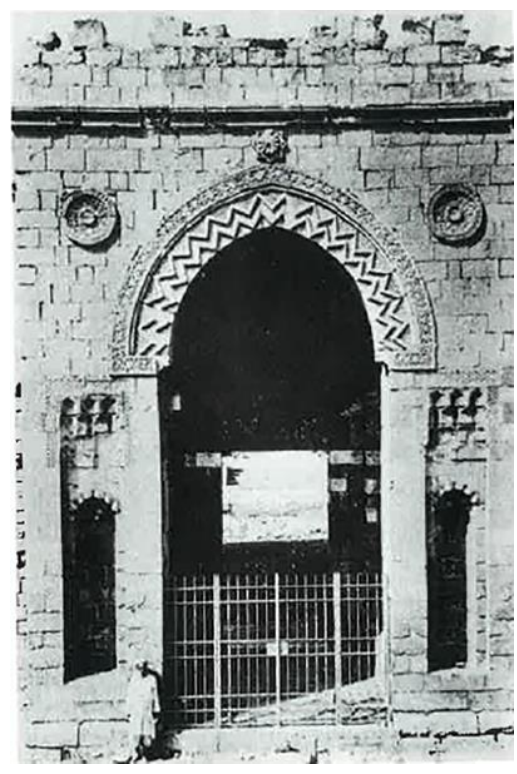

Fig. 18. Kahire Sultan Baybars Cami Kuzeydoğu Taçkapısı (Meinecke 1992, T. 8)

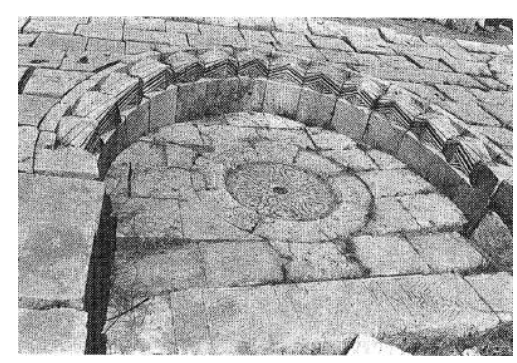

Fig. 19. Trablus Menzil Hanı Taçkapı Kemeri (Salam-Liebich 1983, 172)

Söz konusu yapının sahip olduğu birtakım süsleme ögeleri ve minber ustasının Antepli olması dolayısıyla Suriye-Memlûk ilişkisinin okunabildiği çeşitli araştırmacılar tarafından dile getirilmiştir (Çelik 1995, 558-59; Tanman 2000, 85; Özbek 2002, 207). Benzer kompozisyonda işlenen chevronun diğer Anadolu örnekleri arasında Adana Ulu Cami, Maraş Taş Medrese Türbesi, Mardin Sultan Kasım Medresesi, Antakya Meydan Hamamı ve Hasankeyf Kızlar 
Camii sayılabilir. Kemer alnına ve karnına işlenmiş olan chevron motifi Ortadoğu'da Kudüs'te Mescid-i Aksa'nın kuzey cephesine 1218-19 yılında eklenen revak kemerinde görülmektedir. Ayrıca, Memlûk dönemi eseri olan Trablus Kartaviya Medresesi (1316-26) taçkapısı ve Trablus Menzil Hanı (1309) taçkapısında benzer kompozisyonda işlenmiş chevrona rastlanmaktadır.

\section{Son Söz}

Zikzak, testere dişi ve chevron olarak adlandırdığımız ve aynı kökten çeşitlenen zikzak motifinin, Ortaçağ Anadolu'suna daha çok farklı kaynaklardan aktarıldığı ileri sürülebilir. Kemer ve çevresi zikzak çeşitlemesi hem Geç Antikçağ'da hem de daha yaygın olmak üzere Ortaçağ'da Ortadoğu ve Avrupa'da uygulanmıştır. Anadolu örnekleri ise özellikle Ortaçağ'ın erken ve geç dönemlerine aittir. Dolayısıyla konumuzu oluşturan Anadolu coğrafyasını, günümüze ulaşabilmiş örnekler bağlamında bu çeşitlemede kaynak olarak tanımlamak şimdilik mümkün görülmemektedir. Testere dişi süsleme, her ne kadar Ortaçağ öncesi Lombard coğrafyası ve çevresi bazı mimari örneklerde karşıllı̆ını bulabilse de (Krautheimer 1981, 436) açık bir şekilde Konstantinopolis ve özellikle de Yunanistan'daki Doğu Roma dönemi Orta ve daha sonraları Geç Doğu Roma dönemi kiliselerinde popüler hale gelmiştir. Bu süsleme alışık olmadık şekilde Anadolu'nun V-VI. yüzyıllarına ait iki yapısında kemer üstü uygulama olarak karşımıza çıkmakta ve dolayısıyla bu çeşitlemenin yayılım noktası olarak Anadolu'yu akla getirmektedir. Öte yandan mimarideki testere dişi kullanımlarına işaret eden Ortadoğu ve Avrupa kökenli Geç Antikçağ'a ait minyatür ve fresko örnekleri, Anadolu'daki korunabilmiş en erken (?) iki yapıdaki süslemelerin, henüz ortaya çıkarılmamış olsa bile, diğer coğrafyalarda da eş zamanlı uygulanmış olabileceğine işaret etmektedir. Dolayısıyla Anadolu'daki Geç Antikçağ örneklerinin Doğu Roma'nın çeşitli coğrafyalarında olasılıkla yerel çapta karşılık bulabileceği ve Anadolu'nun Ortaçağ uygulamalarına kökenlik edebileceği olasıllı̆ının şimdilik belirsizliğini koruduğu; Bafa ve Myra'daki Ortaçağ örneklerinin ise coğrafi ve siyasi açıdan yakın temastaki Yunanistan, Adalar ve Konstantinopolis aracılığıyla uygulanmaya başlanmış olabileceği olasıdır. Erken Osmanlı dönemi kemer çevresi testere dişi uygulamalarının genel bir ifade ile 'Doğu Roma' temelli oldukları ileri sürülmüştür. Bölgesel açıdan bakıldığında bu motifin her ne kadar ilk aşamada Anadolu Doğu Roma'sı vasıtasıyla Osmanlı mimarisine aktarılmış olabileceği kabul edilebilse de devletin kısa süre içinde Balkanlara yayılması ile birlikte bu coğrafyadaki testere dişinin yaygın kullanıldığı Doğu Roma kiliselerinden de eş zamanlı etkilenmiş olabilecekleri olasılığı göz ardı edilmemelidir. Chevronun Ortaçağ Anadolu'sundaki etkileşim alanı olarak Suriye görülmektedir. Artuklu ve Anadolu Selçuklu dönemi chevron örnekleri form benzerliği, mimar ve kronoloji açısından bu etkileşimi açıkça gösterir. Erken Osmanlı ve Beylikler dönemi mimarisinde yer alan chevron örneklerinin ise Memlûk mimarisi ile yakın ilişkisi olduğu anlaşılmaktadır. Memlûkluların Ortaçağ Anadolu'sundaki siyasi etkilerinin mimarideki yansıması, içinde chevronun da bulunduğu mimari süsleme detaylarında açığa çıkar. Ortaçağ' da farklı yapı türlerinde uygulandığı görülen chevron motifi, Anadolu'nun geleneksel mimarlık dağarcığında 20. yüzyıl başlarına kadar varlığını sürdürmüştür. 


\section{KAYNAKÇA}

Akyürek E. (1996). Bizans'ta Sanat ve Ritüel: Kariye Güney Şapelinin İkonografisi ve İşlevi. İstanbul 1996. Akyürek E. (2010). "Myra Şapeli Üzerine İlk Notlar". Ed. N. Çevik, Arkeolojisinden Doğasına Myra/ Demre ve Çevresi. Antalya (2010) 153- 160.

Akyürek E. (2015). "A Recently Discovered Thirteenth Century Church at Myra”. Ed. S. Fazlulin \& M. M. Antika, SOMA 2013 - Symposium on Mediterranean Archaeology. Proceedings of the $17^{\text {th }}$ Symposium on Mediterranean Archaeology (25-27 Nisan 2013). (2015) 14-23.

Akyürek E. (2018). “Alakent Kilisesi: Konumu ve Mimarisi”. Ed. E. Akyürek, Alakent Kilisesi Myra'da Bir Bizans Yapisl (12.-13. Yüzyllar) (2018) 59-116. İstanbul.

Altun A. (1971). Mardin'de Türk Devri Mimarisi. İstanbul 1971.

Arık R. (2017). Selçuklu Sarayları ve Köşkleri. Ankara 2017.

Baş G. (2013). Diyarbakır'daki İslam Dönemi Mimarisinde Süsleme. Ankara 2013.

Bayburtluoğlu M. Z. (1973). "Kahraman Maraş’ta Bir Grup Dulkadiroğlu Yapısı”. Vakıflar Dergisi X (1973) 234-250.

Behrens-Abouseif D. (1989). Islamic Architecture in Cairo an Introduction. Leiden 1989.

Bilici Z. K. (2016). Anadolu Selçuklu Çă̆ı Mirası, Mimari. Cilt 1-2-3. Ankara 2016.

Buchwald H. (1979). "Lascarid Architecture”. JOB 28 (1979) 261- 296.

Buchwald H. (1981). "The Church of St. John the Theologian in Alaşehir (Philadelphia)". JOB 30 (1981) 301-318.

Buchwald H. (1984). "Western Asia Minor as a Generator of Architectural Forms in the Byzantine Period, Provincial Back-wash or Dynamic Center of Production?”. JOB 34 (1984) 199-234.

Buhl F. (1977). "Kudüs". İslam Ansiklopedisi. Cilt 6 (1977) 952-964.

Creswell K. A. C. (1979). Early Muslim Architecture. Vol I/Part II: Umayyads A.D. 622-750. New York $1979^{2}$.

Curcic S. (2012). "Divine Light: Constructing the Immaterial in Byzantine Art and Architecture". Ed. B. D. Wescoat \& R. G. Ousterhout, Architecture of the Sacred: Space, Ritual and Experience from Classical Greece to Byzantium. Cambridge (2012) 307-337.

Çam N. (2000). Yunanistan'daki Türk Eserleri. Ankara 2000.

Çelik N. (1995). "Bursa Ulu Camii’nde Güney Tesirleri”. 9. Milletlerarası Türk Sanatları Kongresi. Cilt I (1995) 557-565. Ankara.

Duggan T. M. P. (2017). "İslam Sanatında Zikzak Deseni ve Anlamları Üzerine Bir Okuma”. 21. Uluslararası Ortaçağ ve Türk Dönemi Kazıları ve Sanat Tarihi Araştırmaları Sempozyumu Bildiri Özetleri (25-27 Ekim 2017) (2017) 237- 238. Antalya.

Durukan A. (2007). “Aksaray Sultan Hanı”. Ed. H. Acun, Anadolu Selçuklu Dönemi Kervansarayları Ankara (2007) 141-159.

Enderlein V. (2007). “Mimari”. Eds. M. Hattstein \& P. Delius, İslam Sanatı ve Mimarisi (2007) 64-79. İstanbul.

Erdoğan O. (2015). "The Remains from Late Antiquity and the East Roman Periods and Their Location within the Lydian City of Philadelphia: New Comments". MJH V/2 (2015) 251-274.

Eser E. (2000). 11-14. Yüzyıllarda Anadolu-Suriye Sanat İlişkileri (Cephe Mimarisinde Suriye Etkileri). Yayımlanmamış Doktora Tezi. Hacettepe Üniversitesi, Ankara 2000.

Evcim S. (2015). Dağllk Frigya Bölgesi Bizans Dönemi Kaya Mimarisi. Yayımlanmamış Doktora Tezi. Eskişehir Anadolu Üniversitesi, Eskişehir 2015.

Evcim S. (2016). “Frigya Bölgesi’nde Bizans Dönemi Kaya Mimarisi”. ODÜ 6 (3) (2016) 861- 876.

Freely J. \& Çakmak A. S. (2017). İstanbul'un Bizans Anıtları. İstanbul 2017.

Gündoğdu H. (1986). Dulkadırlı Beyliği Mimarisi. Ankara 1986.

Gündoğdu H. (2002). “Akkoyunlu Devri Mimarisi”. Türkler 8 (2002) 156-165.

Hillenbrand C. (2015). Müslümanların Gözünden Haçlı Seferleri. İstanbul 2015. 
Kaffenberger T. (2017). "Evoking a Distant Past? The Chevron Motif as an Emblematic Relic of Crusader Architecture in Late Medieval Cyprus". Eds. A. Barnes \& M. Salerno, Symbols and Models in the Mediterranean: Perceiving through Cultures (2017) 160-189. Cambridge.

Karydis N. D. (2011). Early Byzantine Vaulted Construction in Churches of the Western Coastal Plains and River Valleys of Asia Minor. Oxford 2011.

Karydis N. D. (2012). "A Monument of Early Byzantine Sardis: Architectural Analysis and Graphic Reconstruction of Building D". AnatStud 62 (2012) 115-139.

Klein H. A., Ousterhout R. G. \& Pitarakis B. (2007). Bir Antt, İki Anitsal Kişilik, Theodoros Metokhites'ten Thomas Whittemore'a Kariye. İstanbul 2007.

Krautheimer R. (1981). Early Christian and Byzantine Architecture. New Haven $1981^{3}$.

Kubach H. E. (1975). Romanesque Architecture. New York 1975.

Mango C. (2006). Bizans Mimarisi. Ankara 2006.

Megaw H. S. \& Hawkins E. J. W. (1962). "The Church of the Holy Apostles at Perachorio, Cyprus, and Its Frescoes". DOP 16 (1962) 278-348.

Mercangöz Z. (1985). Batı Anadolu'da Geç Dönem Bizans Mimarisi: Laskarisler Dönemi Mimarisi. Yayımlanmamış Doktora Tezi. Hacettepe Üniversitesi, Ankara 1985.

Mercangöz Z. (1995). "Batı Anadolu'daki Türk Yapılarının Duvar Tekniği ve Tuğla Süslemelerinin Kaynağı Üzerine Düşünceler”. 9. Milletlerarası Türk Sanatları Kongresi. Cilt II (1995) 485-495. Ankara.

Moss R. L. (2000). Romanesque Chevron Ornament. PhD Thesis. Trinity College, Dublin 2000.

Olcay B. Y. (1990). Kappadokya Bölgesindeki Serbest Haç Planlı Kaya Kiliselerinin Mimari İncelemesi. Yayımlanmamış Yüksek Lisans Tezi. Hacettepe Üniversitesi, Ankara 1990.

Ousterhout R. (2002). The Art of the Kariye Camii. İstanbul 2002.

Özbek Y. (2002). Osmanlı Beyliği Mimarisinde Tas Süsleme (1300-1453). Ankara 2002.

Öztaşkın G. K. \& Evcim S. (2010). "Frigya Bölgesi Kaya Kiliseleri”. Ed. B. Y. O. Uçkan, Frigya (Phrygia) Bölgesinde Bizans Dönemi Kaya Mimarisi (2010) 37- 128. Eskişehir.

Öztaşkın G. K. \& Öztaşkın M. (2012). “Antalya- Olympos Mozaikli Yapı”. Ed. K. Dörtlük, T. Kahya, R. B. Seyhan \& T. Ertekin, Uluslararası Genç Bilimciler Buluşması I. Anadolu Akdenizi Sempozyumu (04-07 Kasim 2009). (2012) 329-346.

Öztaşkın G. K. (2018). “Olympos Episkopeionu Tuğla Süslemeleri”. Eds. T. Kahya, A. Özdizbay \& N. Tünen-Önen, Uluslararası Genç Bilimciler Buluşması II. Anadolu Akdenizi Sempozyumu (04-07 Kasım 2015). (2018) 615- 627. Antalya.

Ricci C. (1925). Romanesque Architecture in Italy. New York 1925.

Salam-Liebich H. (1983). The Architecture of the Mamluk City of Tripoli. Cambridge 1983.

Şancı F. (2006). Hatay İlinde Türk Mimarisi. Yayımlanmamış Doktora Tezi. Ankara Üniversitesi, Ankara 2006.

Tanman B. (2000). "Erken Dönem Osmanlı Mimarisinde Memlûk Etkileri”. Eds. N. Akın \& A. Batur, Osmanlı Mimarlı̆̆ının 7 Yüzyll "Uluslarüstü Bir Miras" (2000) 82-90. İstanbul.

Tanman M. B. (2005). “14. ve 15. Yüzyılların Anadolu Türk Mimarlığında Gotik Etkiler”. Eds. A. Ağır, D. Mazlum \& G. Cephanecigil, Afife Batur'a Armağan Mimarlık ve Sanat Tarihi Yazllarl (2005) 213-225. İstanbul.

Teteriatnikov N. B. (1996). The Liturgical Planning of Byzantine Churches in Cappadoccia. Rome 1996. Uysal A. O. (1985). “Adana Ulu Camii”. Vakiflar Dergisi XIX (1985) 277-284.

Yenişehirlioğlu F. (1989). Türkiye Dışındaki Osmanlı Mimari Yapıtları. İstanbul 1989.

Yurttaş H. (1991). Hasankeyf Yapılarının Sanat Tarihimizdeki Yeri I. Yayımlanmamış Doktora Tezi. Atatürk Üniversitesi, Erzurum 1991. 